\title{
招待論文
}

\section{地球温暖化に関するシナリオとモデル解析 \\ SCENARIOS ON GLOBAL WARMING AND THEIR MODEL ANALYSIS}

\section{松岡 銥*・森田恒幸 ${ }^{* *} \cdot$ 甲斐沼美紀子** \\ Yuzuru MATSUOKA Tsuneyuki MORITA Mikiko KAINUMA \\ * 京都大学工学部衛生工学教室 \\ （ ₹606 京都市左京区吉田本町） \\ ** 国立環境研究所地球環境研究グループ}

Keywords : climate change, global warming, modeling, scenario

\section{1.はじめに}

地球温暖化問題には多くの不確実性が残されている. 炭素循環, 雲の影響, 海洋の影響といった自然の不確実 さとともに，人口成長，経済発展，技術革新などの人間 活動の不確実さがある.このため, 地球温暖化防止に関 する政策展開の方向を決定する場合，将来に向けたいく つもの筋書きを描いていろいろな可能性を見定めること が必要となる．この筋書きを「シナリオ」という.

システム分析においてシナリオという用語は, 従来, 定量的な予測が難しい場合に文章によって将来の状況が 展開していく様子を描写することを意味してきた（クェ イド他, 1972 : 近藤, 1983). このため, シナリオは数 值モデルが使えない場合に用いる一種の代替的手法とし て認識されてきた.しかし，モデリング技術が発達して きた現在, シナリオはモデル解析と政策決定をつなぐ重 要な情報の表現形式として用いられている. 即ち, モデ ルの入力条件やモデルの出力といった定量的な情報のう ち重要なものを明解かつ簡略に記述して, 政策決定者に 伝える表現形式がシナリオと呼ばれるようになった。こ のシナリオを通心て研究者と政策決定者との間のコミュ ニケーションが効率化し, また政策決定の重要な判断材 料として用いられるようになってきている.

地球温暖化の分野においては, 過去 20 年の間に種々 のモデリングが試みられ（松岡・森田，1992）, 数多く のシナリオが描かれできた. 地球温暖化が非常に複雑か つ長期的な現象であり, 多くの不確実さが伴うため, 政 策の検討に当たっていろいろな可能性を見定めることが 不可欠なためである。しかし，これらのシナリオがどの 様な範囲で検討されてきているかを体系的に整理した文 献はなく, また, 不確実な要因を広く勘案した場合によ゙ の様なシナリオが描けるかについて, 総合的に分析した
例はない.

このため本論文では，まず，今までに地球温暖化に関 して描かれたシナリオを体系的に整理する. そして，こ れらのシナリオをもとに入力条件を設定してシミュレー ションを行い, 不確実な要因が複合した場合の温暖化の 程度を予測する. そして,この一連の分析をもとにして， 地球温暖化の不確実さとその政策的意味を明らかにす る.

\section{2. 地球温暖化に関する今までのシナリオ}

地球温暖化の防止策を検討する際に, 政策的に重要と なるシナリオは 5 種類ある. 第一に，人口，経済，技術， など, 温暖化を引き起こす基本的かつ人為的な要因が今 後どのように推移していくかを想定した「前提シナリオ」 がある．これは，現象の不確実さの程度や政策を必要之 する状況を判断するために必要不可欠な情報であり, 政 策判断の基本的前提となる. 第二に，この前提シナリオ で推移したときに,温室効果ガスがどのくらい排出され， 大気中の温室効果ガス濃度がどの程度増加し, その結果 としてどのような気候変化が生じるかを推定した「温暖 化 (気候変化) シナリオ」が必要である. この際, 自然 メカニズムに対する不明さ，不確実さをどのように取り 扱うかが大きな問題となる。 それを勘案し，このシナリ オをどう変えていくかが, 温暖化防止の政策のターゲッ 卜となる，第三に，気候変化が現実のものになったとき に, 自然環境や社会経済によ゙の様な影響が生じるかを推 定する「影響シナリオ」が求められる．温暖化による人 間社会への被害を明確化することによって，温暖化防止 政策の必要性や正当性を意味付けることができる．第四 に，あるレベルに温暖化をくい止めようとしたら，いか なる政策をどのようなタイミングで導入すべきかを提案 した「政策シナリオ」が必要である．政策決定者に与え 
られたそもそもの役割は，このシナリオをつくることで ある. そして第五に，この政策シナリオが実施された場 合にマクロ経済影響などの社会経済的負担がビの程度増 えるかを推計した「費用負担シナリオ」である．政策の 実現可能性を判断するためには，このシナリオが不可欠 である.

以上のシナリオについて，今までに多種多様なものが 描かれてきた。これらのシナリオのうち, まず, 本論文 の目的である地球温暖化見通しの分析のために，今まで に提案された前提シナリオを詳細に分析して, シミュ レーションの入力条件の変動幅を設定する根拠にする. 次いで, 残りの四種類のシナリオの概要を整理して, わ れわれのシミュレーション結果の比較対象を用意する.

\section{(1) 温暖化分析の前提シナリオ}

来世紀に予想される地球温暖化の主な原因は，化石燃 料消費を中心とした人為活動による温室効果ガスの排出 活動であり, その大気中での濃度上昇が温暖化をもたら すとの認識は, 現在, ある程度のコンセンサスを得られ ている.これを基本とするならば，前提シナリオの内で もっとも重要な役割を果たすのは，（1）エネルギー消 費及びそれに伴う温室効果ガス発生のシナリオである. ついで，他の活動である（2）フロン・ハロンの消費／ 排出, (3) 土地利用転換に伴う温室効果ガスの発生活 動, (4) 廃棄物埋立・水処理からのメタン・亜酸化窒 素の発生活動, ( 5 ) セメント生産からの二酸化炭素の 発生活動及び（6）農畜業からの温室効果ガス排出活動 などを考慮する必要があるが,（1）に比べればそれほ ビ大きいものではない.これらの温室効果ガス排出行動 之その将来動向は, 各地域, 地域の人口あるいは経済活 動の程度と深く結びついており，これらをどのように想 定するかが，シナリオ設定の根幹となる.

さらに，こうした人為活動と温室効果ガス排出の間に は, エネルギー効率, サービス効率あるいは排出原単位 などのパラメーターにより集約・表現される技術，ライ フスタイルなぼが関与し，これをどう見積もるかも重要 な課題となる．もっとも影響度が大きいエネルギ一部門 に即して言えば，一次エネルギー量からエンドユーズ段 階のエネルギーサービス量に至る間の各種転換係数と, それに伴う温室効果ガス排出原単位が問題となる。特に, エネルギーの潜在的需要の算出及びこれから二次エネル ギー需要量への転換操作と, その将来動向は, 本問題で 扱っているような超長期にわたるエネルギ一消費の将来 見通しを得る際に，不確定性が入るもっとも大きな要素 である。この部分に関し，しばしば用いられている方法 では，エネルギーサービス及び技術的エネルギー効率の 経時的改善度を，年率で表現する。これを，AEEI (automonous energy efficiency improvements) と称 する. エネルギーサービス需要に対する所得効果あるい

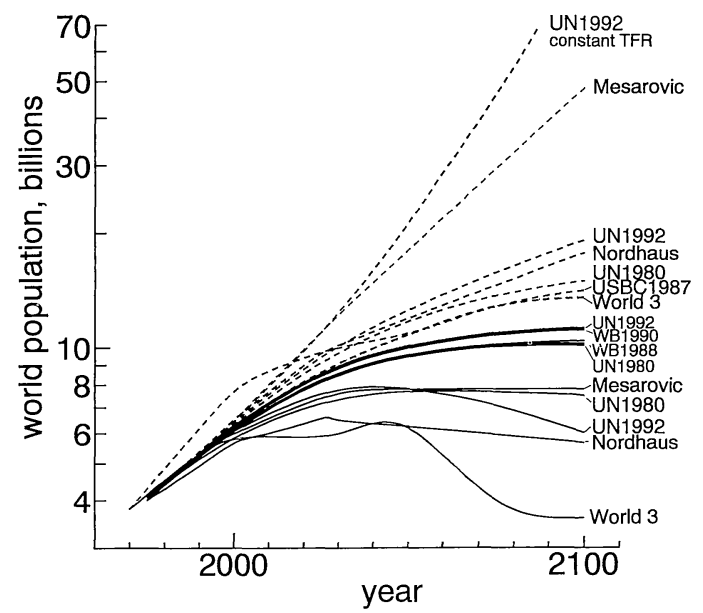

図一1 世界人口の将来推定

破線は，高位側の推計／設定值，実線は低位側の推計／ 設定値.

トーンは，本論文での設定幅を示す.

はエネルギー価格効果を，あらかじめ弾性值表現して排 除するため,このように呼ばれている.この AEEIも， 前提シナリオ中での重要なパラメーターであるが，実態 は不明瞭であり, 通常, 設定值の妥当性を主張すること は困難である。

その他, 太陽エネルギー, バイオマスエネルギーなど 新エネルギーの導入をどのように設定するかなども，前 提シナリオの重要な要素である. ただし, 本論文では, 紙幅の都合上, こうした新エネルギーの積極的な導入は しない場合を想定しよう．そして，以下，順に人口，経 済成長，技術改良（AEEI）に焦点をあて，その設定幅 をさぐってみよう.

まず，人口に関し，現在までに算定あるいは使用され てきた世界人口の見通しを示してみると，図一1のよう になる．図中，破線は，高位側の推計／設定値として提 唱されたもの, 実線は低位側の推計／設定値として提唱 されているものである. 現時点での 50 億人程度を出発 点として, 2100 年には 36 億人 (World 3 モデル設定値) 加 1094 億人 (UN1992) にいたる非常に広い幅をもつ. 極端に大きい値をもつ国連計算値（UN1992）は，2000 年初頭での TFR (合計特殊出生率, 女子が生涯に生む 子供数の平均值）がそのまま継続すると想定した場合で ある. 次に大きい値を示すメサロビッチの高位側設定值 は, 現在の人口増加率が将来にわたっても変化しないと 想定する場合である.これらは，見通しと言うよりも， 思考実験的な值と考えてよい，また，最低位である 2100 年人口 36 億人シナリオはローマクラブによる計算 であり，環境污染による死亡率増加の結果であり，想定 シナリオとしては妥当ではない。これらを除去して検討 するならば, 2100 年人口は 56.6 億人 (Nordhaus, 1983) 


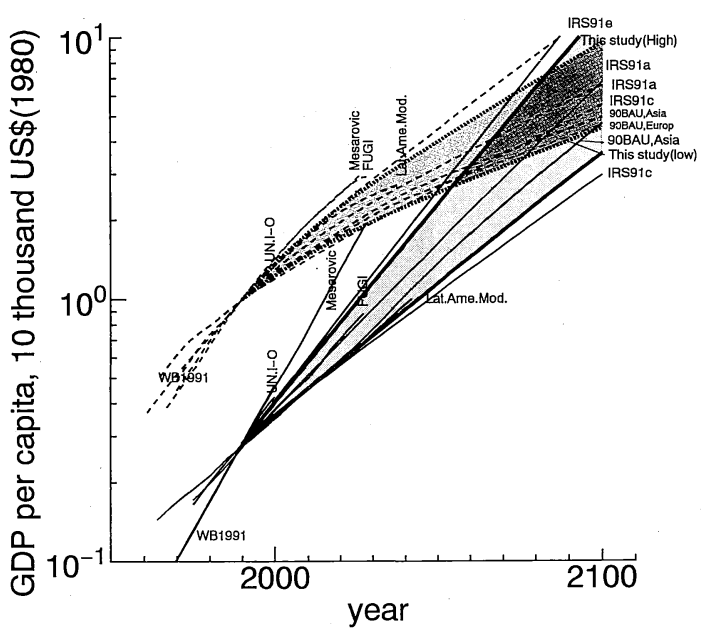

図一2 経済成長の見込み

破線はOECD を，実線はわが国を除く南・東アジアを 示す.

トーンは，本論文での設定幅を示す．

から 191.6 億人（UN1992）となる. 最高位值は TFR 安定値を 2.5 人としコホートモデルから算出したもので あり, 最低位值は TFR をほぼ 1.7 人程度としたものに 相当する.

これらの数值は, わが国に即していえば，それぞれ昭 和 20 年代後半及び昭和 60 年代の出産力に相当し, 将来 可能性が十分ある值である. しかし, 高位推定の場合, 2150 年に 280 億人にも達し, その蓋然性には疑問が提 出されている. また，低位シナリオのような人口減少等 を伴う人口政策に関しては，老齢社会化などの社会的歪 が大きな問題点として指摘されており, 実現性は高くな いと推定される.これらの状況加考えて, 実際上, 問 題となる範囲としては, 最終的な TFR が人口置き換え 水準である 2.1 人となる時期を, 比較的, 早期に見積もっ た世界銀行による 1990 年推計（WB1990, Bulatao ら， 1990）と，その時期を遅く見積もった米国センサス局 1987 年推計 (USBC1987) 程度であろう. 両者は, 来 世紀初頭までは大変似かよった軌跡を示すが, その後離 れていく.WB 1990 の場合，途上国を含めた世界各国 の純再生産率が 2040 年頃までには 1 になると想定し, USBC 1987 では，それを来々世紀であると想定する. 2100 年人口は，WB 1990 では 113 億人であり，USBC 1987 では，135 億人である.

経済成長の見込みに関し, 図一 2 に既往の推定值を示 す. 図中，破線は OECD 諸国を，実線はわが国を除く 南，東アジアの一人あたりの GDP を示す． $90 \mathrm{BAU}$ と は，気候変動に関する政府間パネル（IPCC）が 1990 年に公表したシナリオ（RSWG，1990）にて Business as Usual として設定したもの, IRS 91 とは, 同じく IPCC が，1991 年に行った温室効果ガス排出量見直し

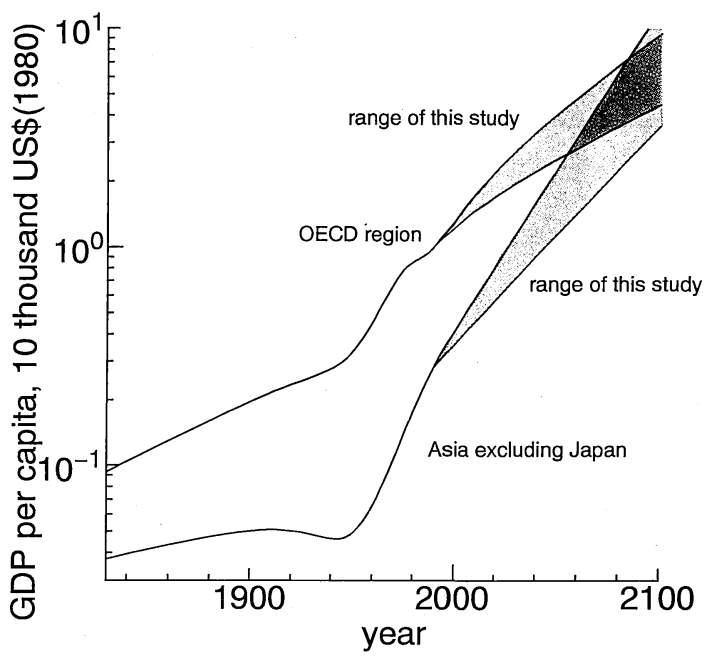

図一3 本論文で設定した経済成長の見込みと過去のトレンド トーンは，本論文での設定幅を示す.

作業にて, 各国からの報告をもとに設定し直したもので あり, IRS 91 a を標準とする.これによれば, 来世紀 初頭までの経済成長率を，OECD 地域にて年率 $2.5 \%$, 途上国にて $4.1 \%$, 世界全体で $2.9 \%$ とし, その後, 0.8 1. 4 \% 低下するとしている. その他の線分は, 他 の世界モデルなどでの設定值あるいは計算値である，先 進国地域に比べ，途上国地域には高い成長率を設定する が, 2100 年までには, 東・南アジア地域を除き, 途上 国地域が先進国地域に追い付くとは設定しないのが通常 である. 図中のトーン部は, IRS 91 a で設定された成 長率を $\pm 20 \%$ した場合の範囲であり, 従来の推定值を ほぼ含む.ただし, 最近の世界銀行による 1990 年台の 経済成長見通し幅（World Bank，1991）と比較してみ ると若干低めとなる。 また，図一 3 は, IRS $91 \mathrm{a} \pm 20 \%$ 幅を過去のトレンドとともに描いたものであるが，やは り低めとなっている.すなわち, 現在まで, 20 世紀後 半に見られた急速な経済成長は, 今後, 安定化の方向に 向かうとの想定が一般的である.

人口成長及び経済成長の設定において, 注意しなけれ ばならないのは, 両者の相関性である. 途上国地域にお ける人口成長率, 特に出生率の低下は, 貯蓄を増加させ 資本形成を促進させる. その結果, 生産性が増大し経済 成長を進展させる. 現在, 特に南アジア地域なざでは, 国レベルの発展シナリオの策定にあたり，このメカニズ ムに強い関心と興味をよせており, それを取り込んだモ デル開発あるいはシナリオ策定努力も盛んに行われてい る(Bilsborrow，1989).ただし，本論文の範囲では， もつぱら議論簡潔化の理由から, 両者は独立として取り 扱うことにしよう.

AEEIに関し，最近のいくつかの代表的なエネルギー 
表一1 既往のモデルにおける AEEI の設定

modelers AEEI

from global energy models

\begin{tabular}{|c|c|}
\hline $\begin{array}{l}\text { Edmonds and Reilly } \\
\qquad(1991)\end{array}$ & $0.5-1.0 \%$ per year \\
\hline $\begin{array}{c}\text { Manne and Richels } \\
\text { (1990) }\end{array}$ & $0.0-1.0 \%$ per year \\
\hline IEA(1991) & $1.1 \%$ per year at OECD \\
\hline GREEN(1991) & $1.0 \%$ per year \\
\hline $\operatorname{IPCC}(1990)^{s}$ & $\begin{array}{l}0.16 \% \text { per year at USA } \\
\text { (Lower Growth Scenario) } \\
0.46 \% \text { per year at USA } \\
\text { (Higher Growth Scenario) }\end{array}$ \\
\hline
\end{tabular}

from feasibility studies of energy efficient scenario

Lovins etalt $^{\text {s }} \quad 1.12 \%$ per year at developed countries

(1981) $1.53 \%$ per year at developing countries

Gordemberg et al. ${ }^{\$} 2.85 \%$ per year at developed countries (1988) $1.40 \%$ per year at developing countries

\$ estimated

モデルでの設定を，表一 1 に示す，省エネルギーに強い 配慮を行わない場合には，年率 $0 \sim 0.5 \%$ 程度，行った 場合は年率 $1.0 \%$ 程度としている. 規範的な省エネル ギーシナリオでは, よ゙の程度か. 例えば, Lovins ら (1981) のシナリオでは; 1975 年から 2080 年の間に, 一人あた りの一次エネルギー消費量を，先進国地域では約 $22 \%$ に，途上国では $50 \%$ に削減している. Gordembergら (1988) のシナリオでは, 1980 年から 2020 年の間に, 先進国地域では一人あたりのエネルギー消費量を $50 \%$ に，途上国地域では $110 \%$ 程度に抑えると想定する. これらのシナリオの AEEI を, 予測期間でのエネルギー 価格及び一人あたり GDP，成長率を勘案して逆算してみ ると, 年率 1.1 2.9\% 程度になる. Gordemberg シナ リオの場合, 計画期間が 40 年と比較的短く, 計画完了 期以降でのいっそうの省エネルギーがかなり困難になっ ていること等を考えると, 年率 $2 \%$ 台を長期にわたり 継続することの可能性は高くなかろう. 従って，これを 除けばAEEI は, 年率 $0 \sim 1.5 \%$ 程度の幅を想定する ことができる．ただし，その程度は，エネルギー消費部 門あるいは地域によって大きく異なることが想定され る.

\section{（2）温暖化シナリオと影響シナリオ}

人口, 経済成長, 技術改良など, 温室効果ガス排出活 動を推定する上での前提が設定されたならば，これらの

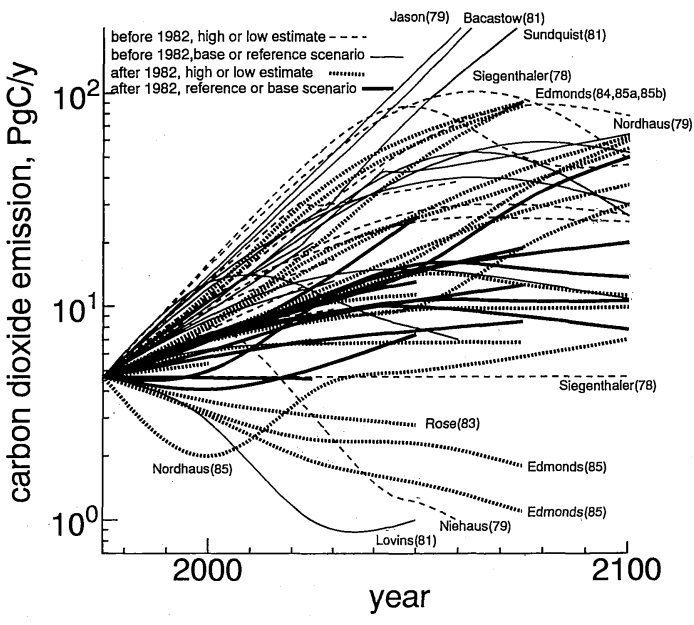

図一4 化石然料消費起源の二酸化炭素排出量見込み 1985 年以前の公表値. $1 \mathrm{PgC}=10$ 億 $\mathrm{tC}$

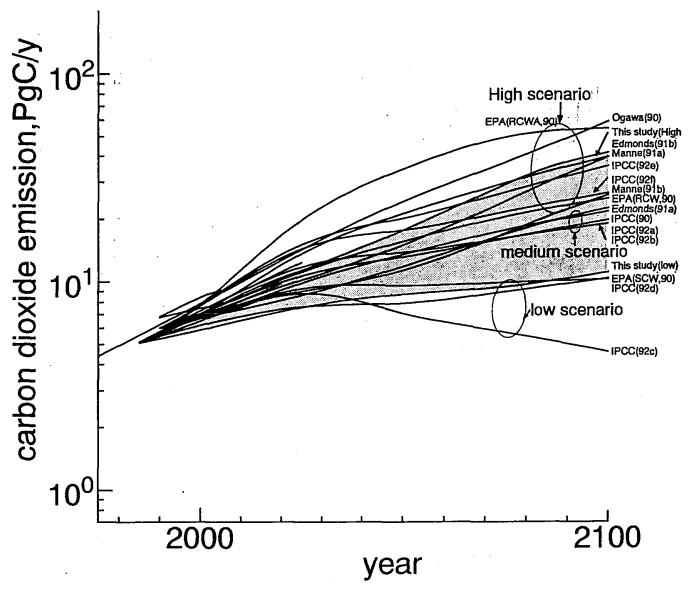

図一5 化石然料消費起源の二酸化炭素排出量見込み 近年の公表值. トーンは，本論文での計算幅を示す.

積み上げにより温室効果ガスの排出量を求めることにな る.

化石燃料消費起源を中心とした二酸化炭素排出量の将 来推定は, 以前から繰り返し行われてきた. それらのう ち, 図一 4 は, 1985 年以前の報告値を示したものである. 2050 年段階にて 10 億 $\mathrm{tC} /$ 年から 1000 億 $\mathrm{tC} /$ 年までの 100 倍にもわたる差異が生じている. 図中で, 実線はレ ファランスシナリオとか, ベースシナリオとかと称され るものである. また, 太線は, 1983 年 1985 年に公表 されたものであるが, 1983 年以降のものはそれ以前の ものにくらべ比較的ま之まりも良く，また，やや低めの 推定を行っている. これは, 1979〜1980 年の第 2 次石 油危機を背景とした省エネルギ一意識の高揚に関連する 亡考えられる. さらに, 図一 5 には, 最近の推定例を示 すが, 地球温暖化問題の高まりと情報普及を背景に, よ 
りまとまった推定幅を示すようになっている.なお，こ の図のトーン部は, 第 4 章での高位及び低位標準シナリ オで挟まれる領域である.

大気中に放出された温室効果ガスは, 移流, 反応なざ の作用を受け，大気，海洋内を循環する。二酸化炭素以 外のガスは, 主に大気中での化学反応により減衰し，ま た二酸化炭素は, 海洋へ取り込まれていく.ここで, もっ とも問題となる部分は, 二酸化炭素のミッシングシンク の取り扱いである. ミッシングシンク量とは，人為起源 排出量, 海洋取り込み量及び大気残留量の収支残差とし て算定されるものであるが，その大きさは 10２0 億 $\mathrm{tC}$ /年 (人為的二酸化炭素発生量の 15 30\%) 程度と考 えられている. 最近のいくつかの報告 (例えばTans ら， 1990）はその実体として, 北半球を中心とした大陸植生 への吸収を示唆するが，河川，降水を通じての炭素移動 に起因させる報告（Sarimientoら，1992）もなされてい る. 現状でもこのような混乱が見られ，将来挙動に関し てはまったく不明である。このような地球内炭素循環構 造に関する不明性は，将来見通しの不確定性の原因とな る.

大気中の温室効果ガス濃度上昇は，気温上昇をもたら すが，これに関しても少なからず問題点がある。いま, 仮に, 地球全体の平均気温のみを取り扱い，それを温暖 化の尺度とする場合を想定しよう。このときにもっとも 重要となる量は, 温室効果ガス濃度上昇による地球平均 温度の上昇値であり, 通常, 二酸化炭素濃度倍増時の平 衡時での気温上昇値 (以下, 気候感度と称する) で表す. この気候感度の大きさあるいは信頼度は, 地球温暖化を めぐる論争の一つの中心である. 温度上昇に伴う水蒸気 量変化, 雪水量変化, 雲量変化などの地球物理学的な フィードバックを考慮しない場合にこの值を算出するこ とは簡単であり，ほぼ $1.3^{\circ} \mathrm{C}$ となる。これに，各種の フィードバック現象が上乗せされ, 気候感度值が求めら れる.この作業には，もっぱら大循環モデル（GCM） を用いる。ただし，現在の GCM 計算で取り上げられ るフィードバック現象は, 上に示した地球物理学的 フィードバックに終始し，下に触れる地球生物，化学的 あるいは社会経済的なメカニズムによるフィードバック を含めないのが普通である.

既往の気候感度報告値のちらばりを，図一6に示す。 横軸に気候感度を, 縦軸に報告値の累積頻度を示したも ので，1.7 5. $2^{\circ} \mathrm{C}$ の範囲を示す.このうち, 下線で示 したものは，モデリング中，特に問題となるミクロ雲物 理過程を取り込んだものであり, 比較的小さい気候感度 を示す. 気候感度の推定幅として, 米国科学アカデミー

(U.S. National Academy of Sciences, 1979) は 1979 年に $3 \pm 1.5^{\circ} \mathrm{C}$ としたが, この範囲は, 最近の IPCC 報告（IPCC，1992）でも追認されている.

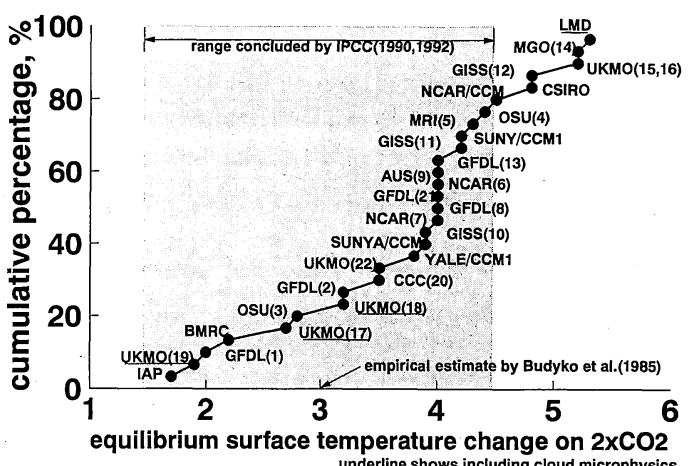

図一6 大気大循環モデルの平衡計算を中心とした気候感度の報 告値の累積頻度

図中には研究機関名及び IP CC エントリー番号が記さ れている.

トーン部は, IPCC が推定した範囲である.

温暖化に伴う地球生物，化学的あるいは社会経済的な フィードバック現象には，数々のものが上げられる．例 えば，二酸化炭素上昇による植物の一次生産量増加とそ れに起因する二酸化炭素吸収量の増加, 温度上昇による 湿地帯あるいは水田加らのメタン発生量の増大，あるい は，大陸棚，ツンドラ地帯に貯蔵されているメタン水和 物の不安定化などを上げることが出来る．これらの フィードバック挙動に対する推測は，信頼性はともかく 不可能ではない。しかし，気候変動に起因する海洋循環 あるいは海洋プランクトン生態系への攬乱とそのフィー ドバック効果などに関しては，その向きについてすら， 定かではない.

このように,気候変動は,さまざまな機構を通じフィー ドバックをもたらすと推測される．しかるにそれらは不 明性が高く, IPCCなどが行っている将来見通し算定作 業においても，考慮されていない。しかし，温暖化シナ リオを策定するにあたり，こうしたメカニズムの存在と 効果がぞの程度のものかを予知しておくことは不可欠で ある。

温暖化に伴う温室効果ガス発生機構を通じてのフィー ドバックとして，比較的よく知られたものとしては，1) 二酸化炭素濃度増大による陸上生態系の一次生産量増 大，2）気温上昇による陸上生態系の炭素保有量変化，3） 気温上昇による湿地帯からのメタンガス発生量増加，4） 気温上昇による大陸棚などのメタン水和物不安定化など がある，そこで，これらについて，概略的なオーダー評 価を行ってみよう.

1) の陸上生態系の一次生産量增加に関しては, 個々 の種での短期的な影響について，いくつかの検討がなさ れている，例えば，図一7は, 純一次生産量 (NPP) 増加之二酸化炭素濃度増加の比（ $\beta$ 係数）に関する報告 值の累積頻度を示したものである. しかし，こうした実 


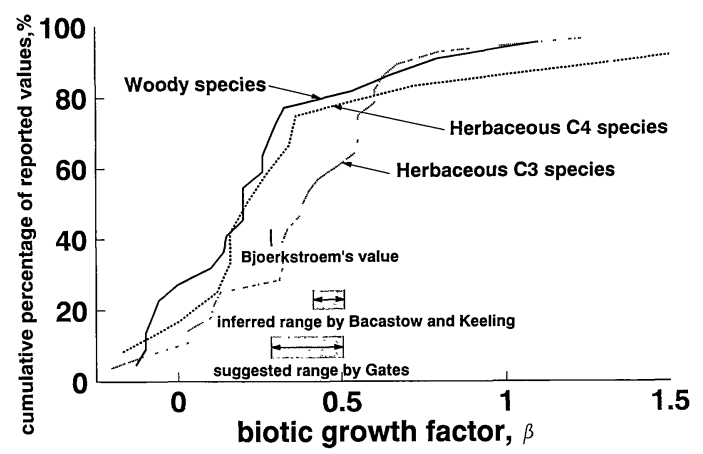

図一7 純一次生産量 (NPP) 増加之二酸化炭素濃度増大の比 $(\beta$ 係数）に関する報告値の累積頻度

験室レベルの植物応答に関する情報を長期的, 地球規模 に積み上げるには不明点が多い.さらに, NPP 増加量 を見積もることが出来ても, それに対する生態系バイオ マス量増加がどの程度かを推定する必要がある.これら に関するとりあえずの見通しとして, 前者に関し, Gates (1985) は地球規模の生物圏のシミュレーション のレビューから, $\beta=0.25 \sim 0.5$ とした. また, 後者に ついて, Shugart (1984) はいくつかの森林動態シミュ レーションの経験から, 植物バイオマスへの効果を 0.2 〜0.6 程度と言う.これらを根拠とし, Lashof (1989) は両係数の中間値を採用して, 二酸化炭素濃度倍増によ る陸上植物生態系の炭素貯蔵量増加を, $0.375 \times 0.4=$ 0.15 , すなわち $15 \%$ 増と見積もった. 現状での陸上植 物生態系の炭素量は, 6000 億 $\mathrm{tC}$ 程度と考えられている から, 二酸化炭素濃度倍増, すなわち, $280 \mathrm{ppmv}$ の濃 度増加で $6000 \times 0.15=900$ 億 $\mathrm{tC}$ の取り込みがあること になる.ただし，このような二酸化炭素肥沃化効果が自 然界にて, 実際にかつ長期間発現するのか, また, 陸上 バイオマス量増加による土中炭素量の増加を, どの程度, 見込めばよいかなど解明すべき点は多い.

2) の気温変化による生態系炭素保有量変化に関して も不明な点は多い. 気候変化による炭素保有量変化を算 定するために, Emanuelら（1985）はGCM の計算結 果から, Holdridge の生態系地域区分を用い, 二酸化炭 素倍増時での温度上昇による生態系変化推定を試みた.

また, Lashof (1987) は, 3 種の GCM 結果（気候感度 3.5〜4. 2 度）を用い, Olsonの植生区分から生態系保 有炭素量変化の算定を行っている. その他, 現在にいた るまでに, Solomon (1986), Woodwell (1986) など いくつかの報告があるが，これらを総合すると $1{ }^{\circ} \mathrm{C} の$ 気温上昇によって生態系から，0〜15 億 $\mathrm{tC} /$ 年程度の 放出があると推定できる，ただ，これらの例は，いずれ も上昇速度が遅く, 生態系遷移が円滑に行われる場合を 想定しているが, 上昇速度が急激な場合には, 生態系の
破壊による上記算定値を上回る排出量も想定される.し かし，その定量的検討例はない.

湿地帯からの土壌細菌によるメタン放出は, 現在のと ころ 1.1 億 $\mathrm{tCH}_{4} /$ 年程度と考えられているが，この量 は気温変化, 水分量変化によりかなり増加することが考 えられる. まず, 土中水分量変化の影響については, 現 在の GCM 結果の地域規模の精度が極めて低いことも あって, 地球規模への積み上げは困難である. そこで, 沼沢・湿地帯分布あるいは水分量状況の変化を考慮せ ず, 温度効果のみを考慮するならば，ある程度の推測は 可能となる. すなわち, 現状の沼沢からのメタン放出の 地域分布として Matthews（1989）による 1 度メッシュ データを用い, 温度上昇パターンとして GISS（気候感 度 $4.2^{\circ} \mathrm{C}$ ), GFDL (気候感度 $4.0^{\circ} \mathrm{C}$ ) 及び UKMO（気 候感度 $\left.5.2^{\circ} \mathrm{C}\right)$ の 3 種の大気大循環モデル平衡時計算結 果（Joseph，1991）を使用し，温度依存性を $Q_{10}$ 表示 で 3.0 , 水点以上の気温時にメタン放出があるとして, 地球平均気温 $1^{\circ} \mathrm{C}$ 上昇時の放出量増加値を求めてみる と，それぞれ，0.20，0.28，0.12 億 $\mathrm{tCH}_{4} /\left(\right.$ 年・ $\left.{ }^{\circ} \mathrm{C}\right)$ となった. Lashof (1989) は, 線度帯別の比較的荒い 計算から， 0.12 億 $\mathrm{tCH}_{4}$ との結果を得ており，ほぼ同じ 範囲にある. 湿地帯以外に, 水田加らのメタン放出にも 同様なフィードバック効果が想定されるが, 温度上昇幅 が小さい低緯度地帯が主対象地域であること, 温度以外 の厳しい制約条件が考えられることなどの理由からここ では取り扱わないこととする.

大陸棚, 永久凍土に埋蔵されるメタン水和物が, 気温 上昇により不安定化し, 大気中に大量に放出されるとの 懸念は, Bell (1982), MacDonald (1983), Revelle (1983) など多くの研究者により指摘されてきた. Revelle(1983) の試算によれば, 大気中の二酸化炭素倍増時における不 安定化が原因となって排出されるメタンは, 年 6.4 億 $\mathrm{tCH}_{4}$ にもなり, Chamberlain ら（1983）によれば, 900 億 $\mathrm{tCH}_{4}$ が数十年間にわたり排出されると言う.しかる に, 近年では, こうした 80 年代前半に提唱された值は 過大であると考えられるようになった（Kvenvolden, 1988). Lashof (1989) は, Revelle (1983), Kvenvolden (1988) などを参考とし, 海底面での温度 $1^{\circ} \mathrm{C}$ 上昇 が年 2.2 億 $\mathrm{tCH}_{4}$ の排出をもたらすとの試算値を報告し ているが，最近の MacDonald（1990）の検討に比べれ ばやや大きい.

以上の例の他に, 数多くのフィードバック機構が示唆 されている. 植生アルベード変化, 海洋循環・海洋プラ ンクトン生態系への攬乱とそれによる二酸化炭素, 熱量 吸収速度の変化は, 将来の気候を大きく変化させるとの 示唆も多い. 不明さと比例するかのようにフィードバッ ク感度も高くなりがちである. Broecker (1987), Lehman ら (1992) は, 気候変化が引き金となる北大西洋 
を中心とする海洋循環変化と, それによるヨーロッパ地 域の急激な気候ジャンプの可能性を示唆しているが，そ の場合には，全世界への影響もまぬがれないであろう. その他, 海洋プランクトン生態系のジメチルサルファイ ド (Charlson ら, 1987), 鉄 (Martin, 1990) などの物 質代謝過程への擾乱が, 海洋への二酸化炭素吸収速度を 大きく変化するとの推測もある. しかるに, 現在のとこ ろ, こうした推測を地球規模に積み上げ, その効果範囲 を判断するには，不明な点が多すぎる.

次に, 影響シナリオについては, 温暖化シナリオに比 ベて研究が大きく遅れている．これは，温暖化シナリオ 自体が多くの不確定要因を含んでいる上に, 地域レベル の詳細な気候変化を予測することが大変難しいことによ る.しかしながら, 現在までに一定の気候変化を仮定し て, 定性的な分析を中心に種々の影響シナリオが描かれ てきた.これらの異なった前提と方法論により独立に行 われてきた研究成果にもとづいて, IPCC の第二作業部 会では, 1990 年に影響予測の報告書（西岡ら，1992） をとりまとめた．影響シナリオに関する研究は, 政策的 重要性から, 現在, 勢力的に行われつつあるが（例えば, Parry ら，1992), 紙幅の都合上,この論文では, ふれ ないこととする.

\section{（3）政策シナリオ及び費用負担シナリオ}

地球温暖化を防止するための政策シナリオについて は，今までに数多く提案されている．このシナリオは, 通常, 政策, 手段及び技術の三つのオプションを組合せ てこれらの導入の時間的スケジュールとともに提案され る. 政策オプションとは各種施策の方針であり, フロン ガスの生産・利用の抑制, 自動車排ガスの規制, 自動車 燃費の改善, 発電の効率化, 太陽エネルギーやバイオマ スエネルギーへの転換, 水田や廃棄物埋立地のメタンガ スの抑制などによって温室効果ガスを減少させる政策の 他に，植林によって二酸化炭素を吸収する政策なよ゙，多 種多様なものがある. 一方, 手段オプションとは政策を 実現するための方途であり，排ガス規制や土地利用規制 のような直接規制の手段, 課徴金や污染税, 污染権取引 制度のような市場メカニズムを活用した手段, 補助金や 開発援助などの財政的手段, 啓蒙, 教育, 訓練などの情 報・教育的手段, 環境アセスメントや計画, 市民参加と いった計画的手段がある.これらの手段は一般化・体系 化され「制度」として定着することが多い. また，技術 のオプションには, 自動車排ガス抑制のための触媒技術, バイオマス・エネルギー利用の促進のためのバイオマ ス・ガス化技術, 二酸化炭素固定化技術など数多くある. このような政策，手段及び技術を組み合わせた最初の 本格的な政策シナリオは, 1989 年の 2 月に米国環境保 護庁の政策オプションレポートによって提案された (Lashof ら，1990).このレポートでは, 来世紀中に温
暖化を止めるためには，単一の対策では無理で，いろい ろな対策を組み合わせて導入することが必要であること が主張された。そして，排ガス規制，省エネ，化石然料 の消費に対する課税, 太陽エネルギー技術の開発, バイ オマスの商業化，原子力の利用などを組み合わせて総合 的に二酸化炭素排出抑制を図り，これに加えて植林やバ イオマスの大規模栽培による二酸化炭素の吸収策, 農業 生産方式の改善や廃棄物の減少によるメタンガスの抑制 策，さらにはフロンガスの規制策も組み合わせて導入す べきとした. また，1989 年に 68 力国が参加して開かれ たオランダ環境大臣会議でも，温室効果ガスの抑制と熱 帯林の植林・保全がセットで検討され，具体的な目標が 宣言された（Mckinsey and Company, 1989).さらに, 1990 年 2 月の米国国務省主催の非公式セミナーでも, 温暖化防止のための総合的アプローチが提案され, 温室 効果ガス全体について多様な削減方策を組み合わせる方 向を打ち出している（The Task Force on the Comprehensive Approach to Climate Change, 1991). 一方, わが国でも 1991 年になって「地球気候安定化に向けた 総合戦略：COSMO プランーI」と題して, 26 の個別 政策プログラムからなる総合的な政策シナリオが提案さ れた (森田, $1990 \mathrm{a}$ ). このプログラムのうち, 都市構造, ライフスタイル, 産業構造等の社会経済システムの基本 構造を変革するプログラムについて, 最近, COSMO プランーIIとして新たな提案も出されている（西岡・森 田，1992）。また，1990年の 10 月にはわが国の政府の 政策シナリオとして「地球温暖化防止行動計画」が策定 され，わが国の二酸化炭素排出抑制目標とともに目標達 成のための各種指針が定められた.さらに，1990年の 10 月には IPCC の最終報告がまとまり, 総合的な対応 戦略とその実施メカニズムが提案され（霞が関地球温暖 化問題研究会編訳，1991)，これを受けて，1992 年 6 月 の地球温暖化枠組条約における政策シナリオの検討へと つながってきている.

さて，以上のような広範囲の政策シナリオのうち，本 論文では経済的手段の一つである「炭素税」に焦点を当 てて検討する，炭素税とは, 温室効果ガスの中でも最も 排出量が多い二酸化炭素を対象にして, 二酸化炭素の排 出量に応じて税金を課することにより，市場メカニズム を通じて効率的な抑制を図るものである (森田, 1990 b). 炭素税は，今までに最も検討が進んでいる手段であり， スウェーデンやノルウェーなどでは既にこの税を導入し ている (Morita, 1992). 以下のシミュレーションでは この炭素税を政策シナリオとして検討するため,この税 の効果や費用に関して, 今までの研究をレビューする.

炭素税の導入及びそれによる世界経済への影響につい ては，今までにいくつかの定量的シナリオが描かれてい る. そして, 炭素税の効果やマクロ経済影響を予測する 
ために，既に 10 以上の数量モデルが開発されている. これらのモデルを使った予測では, 炭素税の税率に大き な幅があり, 炭素税の導入による世界の経済成長率の低 下も年率 $0.3 \sim 0.5 \%$ との悲観的なシナリオから，低下 したとしても $0.01 \%$ 以下であるとする楽観的なシナリ オまでさまざまである（OECD，1991).これらの予測 結果は, 予測の前提シナリオが異なったりモデルの構造 が異なるため, 単純に比較することができない. そこで, 1991 年から経済協力開発機構 (OECD) が中心となって, 同じ前提シナリオの下で世界経済モデルの比較研究が進 んでいる.

OECD の比較研究に参加したモデルは $5 つ$ る. ま ず, Mannら (1991) の開発した Mann-Richel モデル は詳細なエネルギー部門をもつ動学的最適化モデルであ る. バックストップ技術を含めてエネルギーを 9 種に分 類し, 将来の予想をベースにした最適化行動をモデル化 している. 世界を 5 地域に分類し, 石油のみ貿易可能に している. 予測期間は 2095 年までと超長期である.

次に, Edmonds-Reilly モデル (Barns et al, 1991) は, 詳細なエネルギー部門をもつ部分均衡型シミュレー ションモデルであり, 一次エネルギーを 6 種, 二次エネ ルギーを 4 種に分けている. 世界は 9 つの地域に分割さ れ, 化石然料は貿易可能で, 世界的な需給均衡により価 格が決定される.エネルギー部門とマクロ経済のリンク は極めて単純な構造である. 2100 年までを予測対象期 間としている.

一方，OECD は独自のインハウスモデルを開発中で あり, GREEN と呼ばれている（Burniaux ら，1991). これは, 逐次型動学的一般均衡モデルで,一次エネルギー を 4 種, 二次エネルギーを 2 種に分類している. 世界を 9 地域に分割して，完全な貿易リンクをもち，交易条件 変化の影響も考慮される. 国際間で排出権売買をできる ようモデル化されている. 予測期間は 2020 年までであ る.

また，Whalley とWhigle（1991）は，比較静学的一 般均衡モデルにより分析を試みている.このモデルはエ

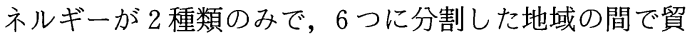
易もモデル化している. 全地域で共通の炭素税を課し, 課税の国際的帰着を分析することを主たる目的としてい る. 1990 年から 2100 年の 110 年間を一期とするため途 中の過程の分析はできない.

以上は, いずれも長期予測モデルであるが, 国際エネ ルギー機関 (IEA) のモデル (IEA，1991）だけは, 2005 年までの中期をターゲットとしたいわゆる計量経 済モデルである. OECD 諸国のみを対象に 10 地域に分 割して, 詳細なエネルギ一部門をもつ. エネルギーの分 類は 5 種であるが，製品の細目は多い。なお，マクロ経 済とのフィードバックはない。
これらの 5 つのモデルを用いて, 人口増加率, 経済成 長率及び資源賦存量に関して同じ前提シナリオを与えた シミュレーションにより，標準ケースの二酸化炭素排出 量の伸びを予測し，次いで，この二酸化炭素排出量の伸 び率を年当たり $1 \% ， 2 \% ， 3 \%$ 低下させる場合の炭 素税の率と GNP の減少率が求められた. 図一8 及び図 ー 9 には $2 \%$ 低下させるケースの予測結果が，二酸化 炭素排出量の削減率と炭素税との関係，並びに，炭素税 と GNP の減少率との関係を表すグラフにして示してあ る. 二酸化炭素排出量増加率を, $2 \%$ 削減するというこ とは, 二酸化炭素排出量を現状レベルで安定化させるか, あるいは少し削減することを意味する政策シナリオであ る.なお，これらの図には，後で紹介するわれわれのシ ミュレーション (AIM) の結果についても併せて載せ ている.

二酸化炭素排出量増加率を $2 \%$ 削減するために, 炭 素税は 1 炭素トン当たり 2000 年で 97 ～ 388 米ドル, 2020 年で 283〜332 米ドルを課するという政策シナリオ となる. また，この課税に伴う費用負担シナリオは，標 準ケースの GNPと比較して，2000 年 $0.3 \sim 3.7 \%$, 2020 年で $1.2 \sim 1.9 \%$ のロスが生じるという予測結果が 出ている.グラフでみると炭素税の効果と経済影響に関 して一定の関係が見られるものの, かなりのバラツキも 見られる.

OECD における検討によれば，予測值が違ってくる 主要な原因として四つの点をあげている. 第一は，エネ ルギー利用効率改善度 (AEEI) に関する仮定で, これ の違いにより標準ケースでの二酸化炭素排出量の伸びが 大きな影響を受ける. 第二は, クリーン・エネルギーを 供給する技術（バックストップ・テクノロジー）に関す る仮定であり, 第三は, 要素代替の弾力性 (ESUB) の值である.いずれも炭素税の税率に直接影響を及ぼす. 第四は，炭素税の税収の還元方法で，この還元をうまく 行うことにより経済への影響を緩和することが可能であ る.

\section{3. 本論文における地球温暖化に関するシナリオ とケースの設定}

第 2 章では, 地球温暖化に関する前提シナリオと温暖 化メカニズムの幅を示したが, 本章では,それらを整理・ 補足しつつ, 本論文の検討で設定したシナリオを中心に 説明を行う.

まず，人口に関しては，低位側を世界銀行が 1990 年 に推計した 2100 年で 113 億人となるシナリオとし, 高 位側を米国センサス局（USBC）が推計した 2100 年で 135 億人となるシナリオとする. また, 経済成長に関し ては, IPCC (1992) が策定したシナリオを中心に, そ の成長率を $20 \%$ 増及び $20 \%$ 減したものを高位及び低 

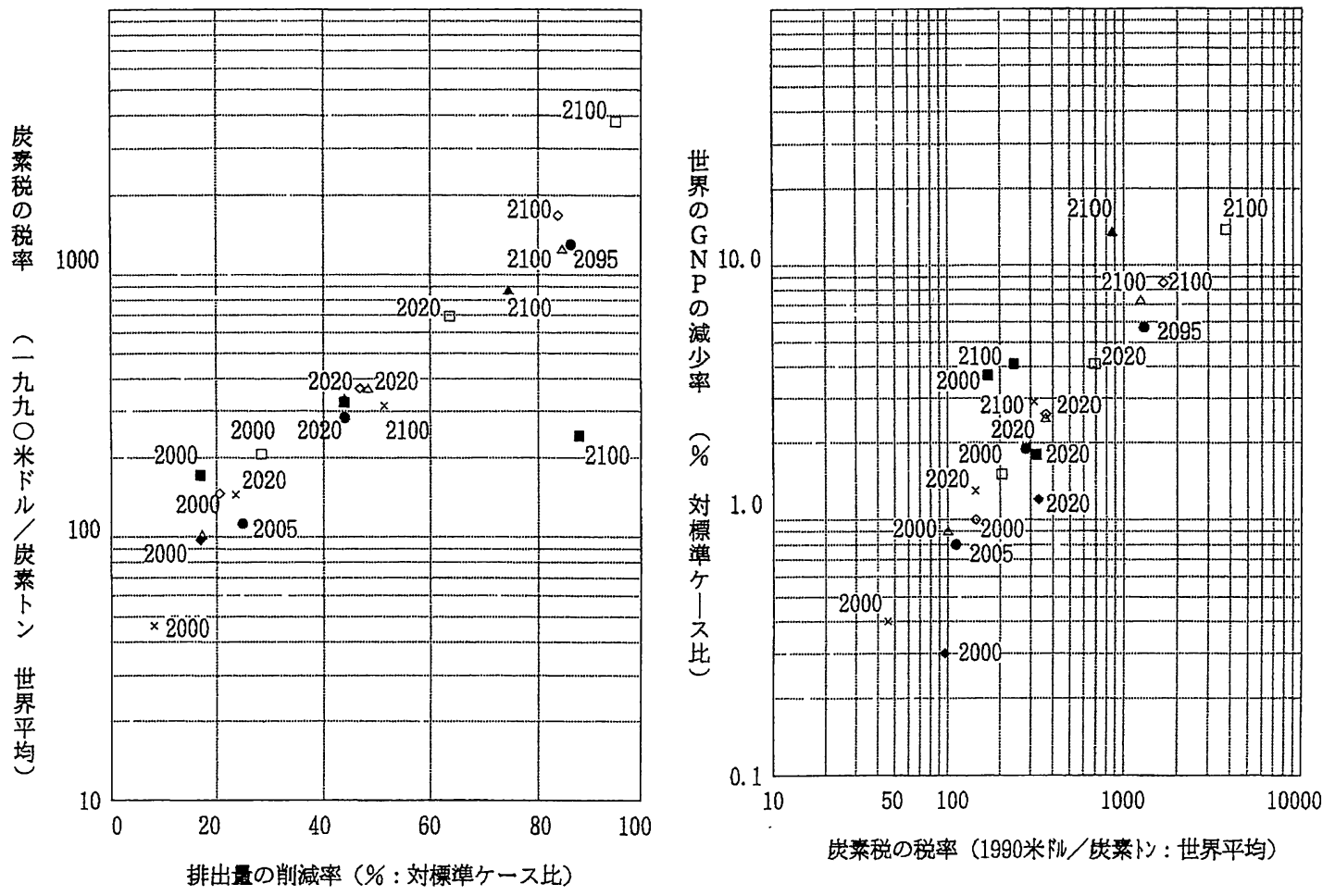

(注 1) : : Mann-Richels Mode1 :Edmons-Rei1ly Mode1

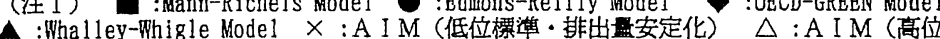

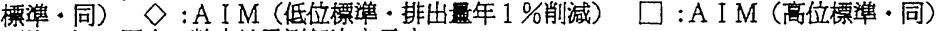
(注 2) 図中の数字は予測年次を示す。

位とする，今世紀中の先進国の経済成長率は $2 \%$ から $3 \%$ となる.

エネルギー最終需要効率改善率 (AEEI) に関しては, 高効率化シナリオとして, 米国環境保護庁 (USEPA, 1990）が策定した急変化社会シナリオのベースとなった エネルギー需要を，低効率化シナリオとしては，緩変化 社会シナリオのベースとなったエネルギー需要を基礎と する，これは，先進国地域については Mintzer（1988） により，途上国については，Sathaye ら（1988）による エンドユーズ型の積み上げ值であり，AEEI 值はこれか ら逆算して求めることにする.

フロン，ハロン等のオゾン層破壊に係わる温室効果関 連ガスに関しては, モデルでは, 10 種を取り扱っている. このうち，規制物質である CFC-11， CFC-12 なよ゙の 9 種については，モントリオール議定書第 2 回締約国会 合（1990 年 6 月）での削減スケジュールをもとに，こ れへの先進国参加率を $100 \%$ ，途上国参加率を $85 \%$ と して策定した. また，過度的物質である HCFC-22に ついては，UNEPなどに報告されている消費量見通し から，今世紀中にて約 $4 \% /$ 年程度，来世紀半ばまでは $2.5 \% /$ 年程度の増加があり, それ以降には一定となる
ように仮定した. フロン，ハロンに関しては，1992 年 11 月に開催されるモントリオール議定書第 4 回締約国 会合にて，より厳しい規制がなされる見込みであるが, 本論文では，前記の規制スケジュールとし，シナリオ間 で変えていない。

森林破壊を中心とする土地利用転換部門の前提シナリ オとしては, 人口増加を主因として推定されたアジア 16 力国, アフリカ 36 カ国, ラテンアメリカ 23 力国で の森林量変化予測シナリオ（Houghton, 1990）を使用 した. 現状の森林消滅速度は指数的に増加し, 来世紀半 ばに 3400 万 ha／年に達し，来世紀末には熱帯森林はほ ぼ消滅すると想定するものである.

その他, 都市廃棄物埋立からのメタン発生, セメント 生産工程からの二酸化炭素排出, 農業活動からの各種の 温室効果ガスの発生に関しては, 人口成長, 一人あたり GDP 増加などから推定し, 特に抑制対策を行わないも のとする.

次に, 温暖化機構に関するシナリオとしては, 2. ( 2 ) で述べた気候感度及び各種フィードバックメカニズムを 組み合わせ設定するものとする.

まず，ミッシングシンクに関しては，その実体及び将 
来動向共に不明である.そこで，次の 3 つのシナリオを 想定しその不明さに対応しよう.その 1 は，計算期間中 シンク量を一定とし，1985 年での值 (14.3 億 $\mathrm{tC} /$ 年) を採用するものである．これを標準とする．その 2 は， シンク量を大気濃度に比例させるものである．なんらか の負フィードバックを想定するものである. その 3 は, 将来, このシンク量は期待できないと考えるものであり, 例えば年率 $2 \%$ で減衰させるものである.

次に，気候感度に関しては，標準値を $3{ }^{\circ} \mathrm{C} と し ，$ 低， 高位值としては，これに $1{ }^{\circ} \mathrm{C}$ の増減を加えた $2{ }^{\circ} \mathrm{C}$, $4^{\circ} \mathrm{C}$ とする

フィードバックメカニズムに関しては，2（２）で取 りまとめた $5 つ の$ 機構のオプションを準備する. その第 一は, 二酸化炭素による肥沃化効果である. これは負の フィードバック効果である. 取り込み量は, $\mathrm{CO}_{2}$ 濃度 に比例させ, 濃度倍増時 ( $280 \mathrm{ppmv}$ 増加)で 900 億 $\mathrm{tC}$ と する．第二は気温上昇が原因となって，陸上生態系で貯 蔵していた炭素を放出する効果である．2.（2）で示し た幅はかなり広いが，ここでは仮に 5 億 $\mathrm{tC} /\left(\right.$ 年 $\left.{ }^{\circ} \mathrm{C}\right)$ す る.第三は, 気温上昇に基づく土壌中のメタン細菌活動 の活発化による $\mathrm{CH}_{4}$ 排出量の増加である. これについ ては，2.（2）で求めた三数值の平均值である 0.20 億 $\mathrm{tCH}_{4} /\left(\right.$ 年・ $\left.{ }^{\circ} \mathrm{C}\right)$ を採用する. 第四は, 気温上昇による メタン水和物不安定化の効果である. これに関しても不 明な点が多いが，とりあえず，地表気温 $1{ }^{\circ} \mathrm{C}$ の上昇に より, Lashof の報告値の半分である 1.1 億 $\mathrm{tCH}_{4} /$ (年・

$\left.{ }^{\circ} \mathrm{C}\right)$ を採用しよう.

フィードバック機構に関する第五の例として, 上に述 ベたメカニズムに比べれば確度は低いが，全く排除する こともできないものとして, 海洋表層温度の上昇值が産 業革命前にくらべ, ある一定値, 例えば $2{ }^{\circ} \mathrm{C}$ を超えた 場合に, 海洋循環に大きな変化が生じ, 二酸化炭素及び 熱量の海洋吸収がシャットダウンされるとのオプション を用意しよう.

以上のシナリオ及びオプションを組み合わせ，本論文 では下のようなケースを検討する.

まず,温室効果ガス排出に関する前提シナリオとして, 人口，経済成長及び AEEI の各要素を組み合わせ，以 下の標準ケースを作成する。この際, 温室効果ガス抑制 対策を取り立てて行うことはしない.

（1）高位標準シナリオ：高位人ロシナリオ（米国セ ンサス局推定, 2100 年 135 億人) +高位経済成長 (IRS 91 a 成長率 $20 \%$ 増) +低効率化シナリオ

（2）低位標準シナリオ：低位人ロシナリオ（1990 年世界銀行推定, 2100 年 113 億人) +低位経済成 長 (IRS 91 a 成長率 $20 \%$ 減) +高効率化シナリ 才

これに，温暖化抑制対策の例として，炭素税の導入を
行い, 二酸化炭素排出量の安定化および削減を行うケー スを想定する. 排出量安定化ケースでは, 1990 年以降, 排出量伸びを止めるような炭素税の賦課を行う．税率は 世界一律とする. この場合, 賦課率は前提シナリオに大 きく依存する．標準ケースの二つのシナリオに対応した 高位あるいは低位の賦課率とそれによるマクロ経済影響 が算定される. 排出量削減排出のケースとしては, 来世 紀末までに, 大気二酸化炭素濃度の安定化を図ることを 大略のメドとして，削減率を年率 $1 \%$ とした場合を想 定しよう. 基準年は 1990 年とする.この場合においても, 標準ケースの二つのシナリオに対応し二つの賦課率とマ クロ経済影響の経時的軌跡が算定される.

ミッシングシンク，フィードバックなどについては, 検討を簡単にするために，標準的メカニズムを基本とし て, 高位側, 低位側に次の順番で機構付加を行うことに する.

まず，高位側には，（1）ミッシングシンク量の年率 $2 \%$ 減少, ( 2 ) 正のフィードバック機構, すなわち, 陸上生態系代謝量増加, 湿地帯加らのメタン排出増加, 水和物不安定化の付加, ( 3 ) 海洋循環の変化, を順に

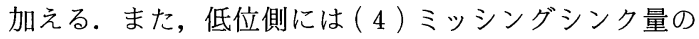
大気濃度との比例仮定, ( 5 ) 負のフィードバック機構, すなわち, 二酸化炭素による肥沃化効果, を順につけ加 えることとする.

\section{4. シミュレーションによる温暖化及び政策シナ リオの分析}

\section{（1）検討に使用したモデルの概要}

本検討には，著者らが開発中のシミュレーション・モ デル（アジア太平洋地域温暖化対策分析総合モデル： AIM）を用いた.このモデルは, 主にアジア太平洋地 域の温暖化防止対策を検討するために開発しているもの であるが，世界規模の予測も可能なように世界モデルと リンクしている.この世界モデルには, 米国環境保護庁 で開発された大気安定化フレーム (ASF) を出発点と して，これにいくつかのサブモジュール及び入力データ を追加, 置換あるいは更新したものを用いている(松岡, 1990, Matsuoka，1992). 世界の地域区分に関し，本論 文で示すものは，エネルギー関連部門では 9 地域，他の 部門では現象に応じて 1 ボックスから数十ボックス（地 域）分けを行っている. 計算対象期間は, 原則として 1985 年から 2100 年であるが, 炭素, 熱循環などでは 1830 年から助走計算を行っている. また, 対象とする 温室効果関連ガスは, 二酸化炭素, メタン, 亜酸化窒素, フロン・ハロンなど 15 種である.

AIM は, 人為起源の温室効果ガス発生・吸収モジュー ル, 自然起源の温室効果ガス発生モジュール, 及び地球 規模の温室効果ガス循環・温度上昇モジュール及び 


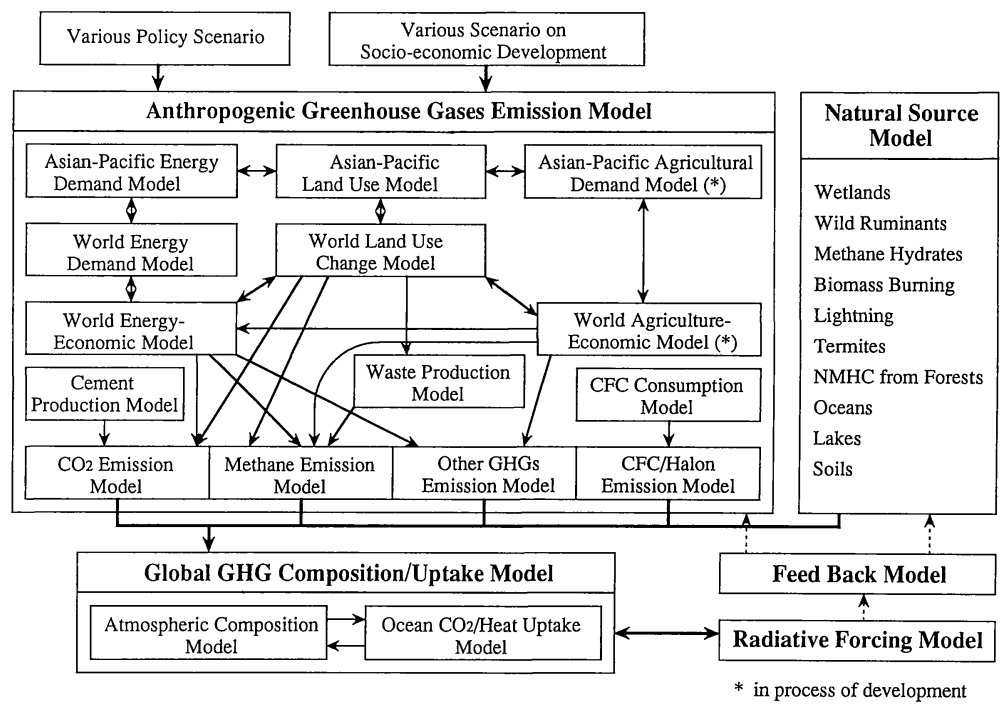

図一10 アジア太平洋地域温暖化対策分析総合モデル：AIM の概要

フィードバックモジュールから構成されている（図一 10). 人為起源の温室効果ガス発生・吸収モジュールは, 人口，経済成長及び資源ベースをシナリオとして与え， エネルギー・モデル, フロン・ハロン排出モデル, セメ ント $\mathrm{CO}_{2}$ 排出モデル, 都市廃棄物からのメタン発生モ デル，農業活動からの温室効果ガス排出モデル，土地利 用変化からの $\mathrm{CO}_{2}$ 排出・吸収モデルなどから温室効果 ガス排出総量を体系的に推計する仕組みになっている. 人為起源の温室効果ガス発生部門の中核をなすエネル ギー・モデルは，エネルギー需給に関する部分均衡型モ デルであるエドモンズ・ライリー・モデル (Edmonds ら，1983）を基本にして，エンドユーズ・モデルとの結 合, 資源供給のより実際的なモデル化, エネルギー消費 部門の精細化，エネルギー機器・資本のビンテージモデ ル化など大幅な改良を行っている.

大気中に放出された二酸化炭素以外の温室効果ガス は，化学反応なよ゙により徐々に減衰する，モデルでは, 対象となる化学種を, 反応時間が比較的長いフロン, 八 ロンあるいはメタンのような長期種と, 反応速度が大き いオゾン, 水酸ラジカルなどの短期種とに分け, 後者に ついては擬平衡状態を想定する. その上で, 対流圏での $\mathrm{OH}$ ラディカルが中心となる $\mathrm{CH}_{4}$ 等の酸化反応と光化 学反応などを取り上げ，それらの反応速度と各化学種濃 度変化の間を簡単な代数式で定式化している.

二酸化炭素の海洋吸収については，以下の検討では， ボックス拡散モデルを使用している。このモデルでは, 全海洋を深さ $100 \mathrm{~m}$ 程度の表面混合層と, その下, 約 $1000 \mathrm{~m}$ の深さの中層海洋に分割する. そして, 大気か ら吸収された二酸化炭素は, 無機炭素として表面混合層 内に均質に混合し，しかる後に中層海洋に拡散していく
という機構を考える. $\mathrm{CO}_{2}(\mathrm{aq})$ 加ら $\mathrm{HCO}_{3}{ }^{+}$あるいは $\mathrm{CO}_{3}{ }^{3+}$ への解離は, 全ほう酸量, アルカリ度, 塩分量及 び水温の影響を考慮しながら，化学平衡式を解くことに よって求めている. 大気反応あるいは海洋の二酸化炭素 取り込みモデル中に出現する反応速度, $\mathrm{CO}_{2}$ 移動係数, 鉛直拡散係数などの温度依存性は，モデル中に組み込ん でおり，フィードバック効果の項としては取り上げない ことにする。

温室効果ガス濃度の増加による増加放射加熱量の算出 には，既往の放射対流モデルの計算結果などを参考とし て作成した回帰式を使用した. 増加放射加熱量 $\Delta Q$ 亡上 昇温度 $\Delta T$ の関係は, 次のような簡単な, 地表面付近の 熱収支式である

$$
\Delta Q-\lambda \Delta T=F
$$

を想定する．ここに $F$ は海洋の熱吸収フラックスであ り，入はフィードバック係数と呼ばれる定数である。 の值は，気候感度を $3{ }^{\circ} \mathrm{C}$ とれば，二酸化炭素倍増時 (280 ppmv から $560 \mathrm{ppmv}$ を想定) の $\Delta Q$ を $4.3 \mathrm{w} / \mathrm{m}^{2}$ として，1.43 w/ $\left(\mathrm{m}^{2} \cdot \mathrm{C}\right)$ となる. $F$ は, 二酸化炭素 と同じくボックス拡散モデルで算定している.

\section{（2）シミュレーションによる検討}

前提シナリオに基づき算定した化石燃料消費起源の二 酸化炭素排出量を, 図一11に示す. 二つの標準シナリ オのもとで二酸化炭素排出量を予測すると, 2025 年で 1.4 倍〜2. 4 倍, 2100 年で 2 倍〜 7 倍の範囲で増加する. その結果, 2100 年排出量は, 高位標準シナリオの場合, 397 億 $\mathrm{tC} /$ 年に, 低位標準シナリオの場合, 112 億 $\mathrm{tC}$ /年となる.これを, 既往の報告值と比較したものは, すでに，図一 5 に挙げている，近年の報告值幅とほぼ対 応していることがわかる. 


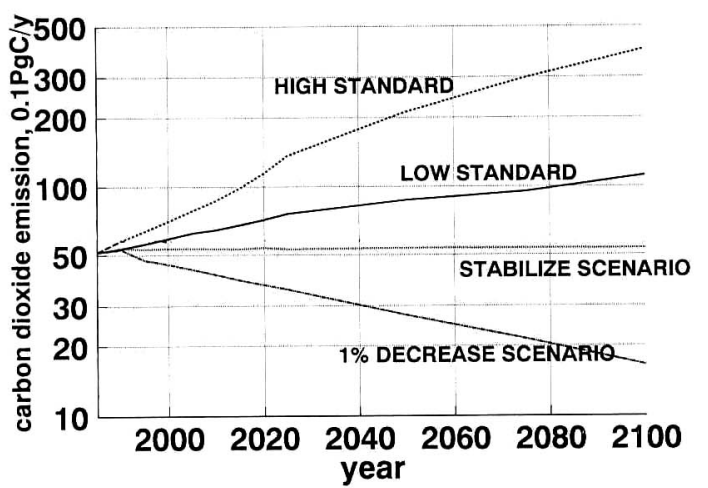

図一11化石然料消費起源の二酸化炭素排出量

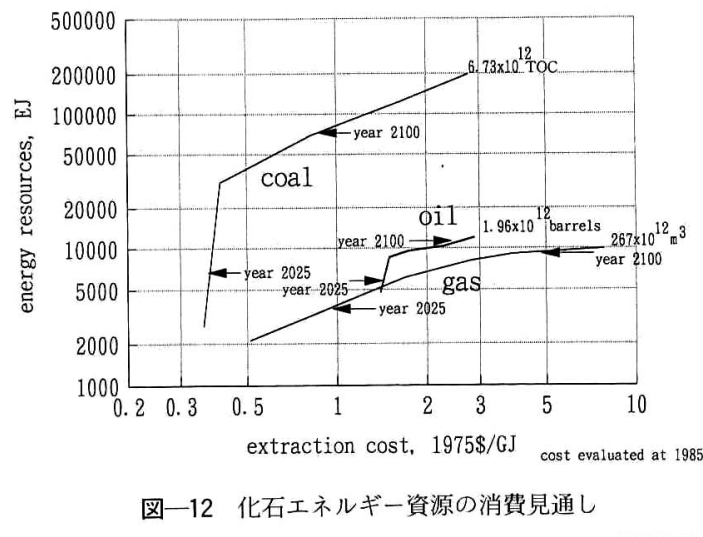

図一12 は, 高位標準シナリオにおける化石エネルギー 資源消費の軌跡である．縦軸に資源量を，横軸に採掘コ ストを取った資源・コスト曲線上での，2025 年及び 2100 年の位置を示したものであるが, 本設定シナリオ のような化石然料消費を行ったとしても, 石油及び天然 ガスについては, 来世紀の末までに経済的埋蔵量の大部 分 (90\% 程度) を消費するが，石炭については $37 \%$ 程度しか消費していない，すなわち，化石燃料の枯渇に より地球温暖化問題が解決するという見込みは,この先 百年は考えにくいことになる.

次に, 炭素税の導入を図り,排出量安定化及び年率 $1 \%$ 削減を行うケースについて, 政策遂行に要する税率を図 -13に示す. 経時的に高率の賦課が必要となり, 安定 化ケースの場合, 2025 年で 1 炭素 $\mathrm{t}$ 当たり 180 米ドル －440 米ドル，2100 年で 310 米ドル〜 1250 米ドルの範 囲となる。また，これによる世界 GNP の娍少率を図一 14 に示すが, 安定化ケースにて, 2025 年で $1.5 \%$ 2.8 \%, 2100 年で $2.8 \%$ ～ $7.3 \%$ の範囲となる. ここに示 した税率及び GNP 影響の算定結果と他の世界モデルで の算定結果の比較は, すでに, 図一 9 に示したが, それ によれば，他のモデルによっても，ほぼ同様の結果を得 るであろうことが推定される. 以上から, 排出量安定化 を, 炭素税による抑制対策により行う場合, 高位標準で

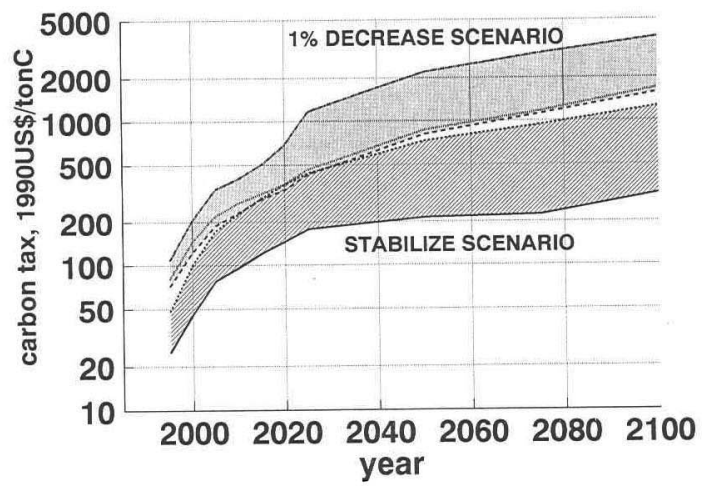

図一13 炭素税税率の経時的変化 トーン部は設定シナリオの差による幅である.

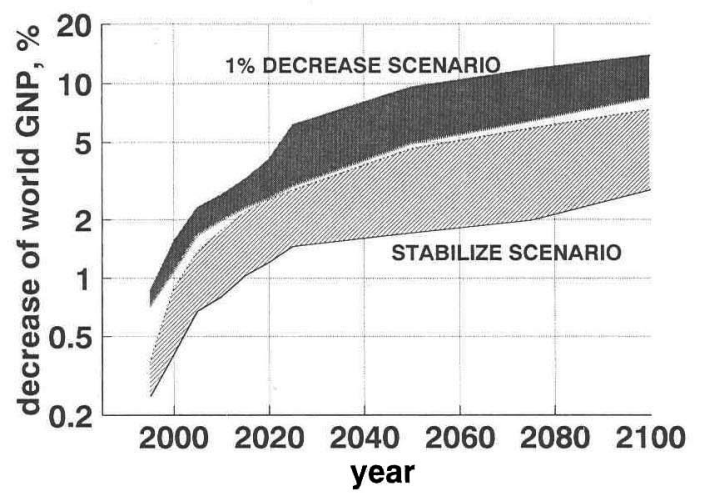

図一14 世界 GNP の減少率

トーン部は設定シナリオの差による幅である.

あっても, 潰滅的なマクロ経済影響をうけるとは, 想定 できない.

後に示すように，二酸化炭素排出量の安定化だけでは 温暖化は止まらない。 もっと箃しい対応が必要である. 毎年 $1 \%$ を削減するシナリオでは，来世紀末に炭素税 が 1 炭素 $\mathrm{t}$ 当たり 2000 米ドル以上にもなる可能性があ るが，それでも温度上昇は続く．植林，ソーラ一やバイ オマスのエネルギーコストの低減等を含めた総合的な対 応の必要性を改めて認識させる.

次に, 図一15に, 温室効果ガス濃度の経時変化を示す. 図一15 (a) は標準ケースを示したものであり,ミッシン グシンク (図中には MS と記す), 正, 負のフィードバッ ク機構及び海洋吸収のシャットダウンの効果が記されて いる.こうした機構のつけ加えにより, 設定シナリオに よる広がり幅は，いっそう大きくなる．2100年にて， 図ー15 (a)に示す標準ケース場合では, 819 1846 ppmv から 690－2379 ppmvに，図一15 (b) に示す安定 化ケースでは, 713 ppmv が 617 -872 ppmvに，図一15 （c）に示す年率 $1 \%$ 削減ケースの場合には, 573 ppmv が 518〜 780 ppmv となる. 同様の広がりは，上昇温度 幅にも見られる，図一16 (a)，（b)，（c）はそれを示し 


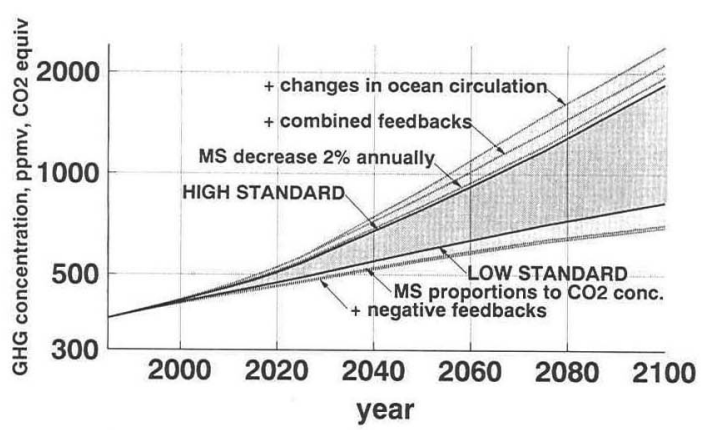

図一15（a）温室効果ガス濃度の変化 標準ケースの場合, 気候感度 $3^{\circ} \mathrm{C}$

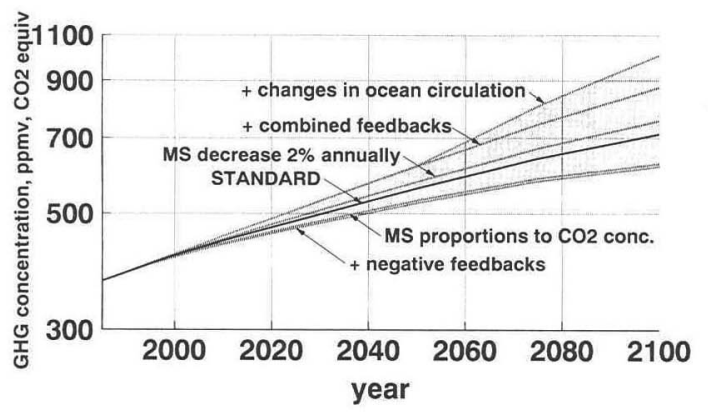

図一15 (b) 温室効果ガス濃度の変化 排出量安定化ケースの場合, 気候感度 $3^{\circ} \mathrm{C}$

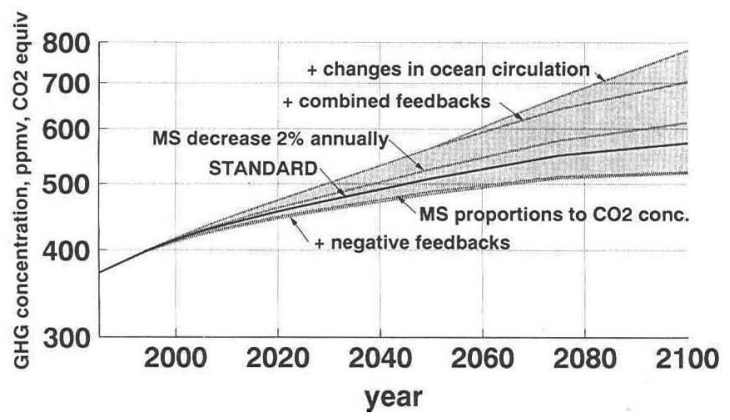

図一15 (c) 温室効果ガス濃度の変化 年率 $1 \%$ 削減ケース, 気候感度 $3{ }^{\circ} \mathrm{C}$

たものである. この場合, 海洋循環変化の影響が, 大変 大きく表れているのが特徴的である. 図一16 (c) に見ら れるように, 年率 $1 \%$ 削減ケースにおいても来世紀中 に温度上昇を止めることは出来ない. 図一15,16は， 気候感度を $3{ }^{\circ} \mathrm{C}$ とした場合であるが，これを $2 ， 3$ ， $4{ }^{\circ} \mathrm{C}$ とした結果を図一17に示す，図には，今までの各

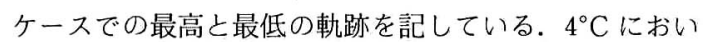
ては, 2080 年にて $2.2 \sim 10^{\circ} \mathrm{C}$ にも及ぶ幅が生じている.

\section{（3）モデルによるシナリオ分析の解釈}

4. (2) での結果から, 以下の解釈を行うことができ る.

1) 地球温暖化現象の不確実さには, 社会経済的要因 亡自然的要因のいずれもが大きく効いている. 社会経済

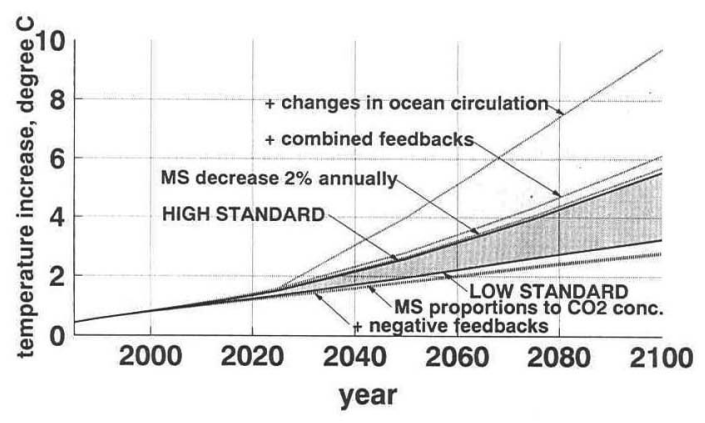

図-16（a）温度上昇の経時的変化 標準ケースの場合, 気候感度 $3^{\circ} \mathrm{C}$

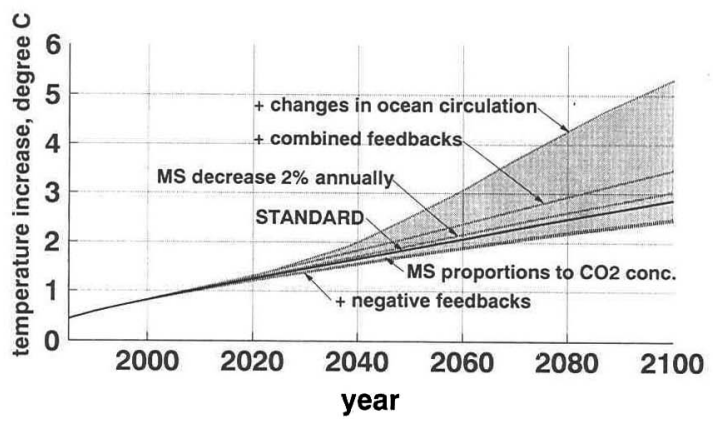

図一16 (b) 温度上昇の経時的変化 排出量安定化ケースの場合, 気候感度 $3^{\circ} \mathrm{C}$

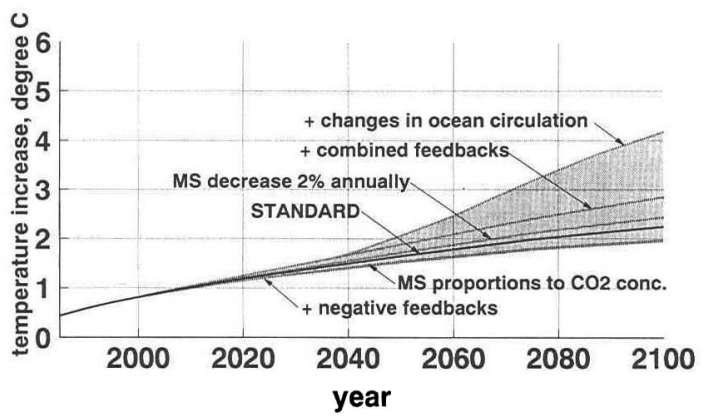

図一16 (c) 温度上昇の経時的変化 年率 $1 \%$ 削減ケース, 気候感度 $3{ }^{\circ} \mathrm{C}$

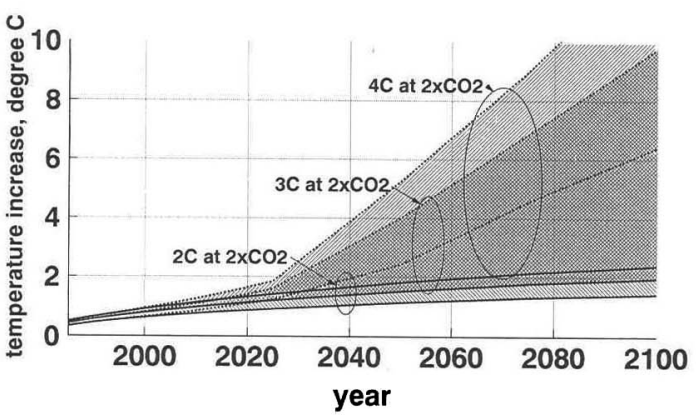

図一17 気候感度 $2 \sim 4^{\circ} \mathrm{C}$ での気温の上昇 標準, 安定化, 年率 $1 \%$ 削減ケースを併せて示す 
的要因の不確実さの方が相対的に大きい可能性もある.

2) 地球温暖化の予測值は大きくばらつくが，地球温 暖化の予想をくつがえすことは難しい.

3）二酸化炭素排出量安定化に要するコストも大きく ばらつくが，その影響は潰滅的とはいえない.

4）二酸化炭素濃度安定化のためには本検討では取り 上げなかった対策オプションを含めた総合的な対応が必 要である.

5）化石然料資源が来世紀末に枯渇することは想定で きない.

\section{5. おわりに}

本論文では，地球温暖化に関するシナリオをシミュ レーション・モデルを用いて策定・分析することによ り，地球温暖化及びその抑制の見通しと不確実さについ て検討した．本分析の結果を，政策的問いに対応させて 次のようにまとめることができる.

1）地球は本当に温暖化するか?

今までに得られた科学的知見と将来の発展に対する認 識を前提にすれば, 地球の温暖化を否定することは困難 であり, 温暖化の可能性は非常に高いといえる. 地球温 暖化は現実の政策課題と認識すべきである.

2) 地球温暖化の不確実さはよ゙の程度か?

社会経済的な不確定要因亡自然の不確定要因の両方を 勘案すれば不確実さの幅は非常に大きく, 温暖化の程度 は来世紀末で少なくとも $1.5^{\circ} \mathrm{C}$, 最悪の場合には $10^{\circ} \mathrm{C}$ を超えると推定される（いずれも産業革命前と比較した 場合, 以下同じ). これは, 今までに認識されている不 確実さの幅 (例えばIPCC の結果) よりもさらに大きく, これに対する政策対応を検討する必要がある.

3）不確実さの幅に対してよ゙う政策対応すべきか? 今回明らかにした不確実さの幅は, 現段階での政策才 プションの確定が困難であることを示している．気温上 昇が $1.5^{\circ} \mathrm{C}$ か $10^{\circ} \mathrm{C}$ 以上かでは政策オプションの選択が 本質的に異なる．従って，現時点の政策展開としては， 第一に，不確実さに対応した幅広い政策オプションを検 討すること，第二に，不確実さを减らすための努力を続 けること，第三に，最悪の事態に備えた手を今から打っ ておくこと，が基本となる.

4) 政策オプションはどの範囲で検討すべきか?

来世紀中に温度上昇を止めること（気候安定化）を政 策目標に設定すれば，今までに提案された政策オプショ ンよりさらに厳しい温暖化防止対策, 例えば, 社会経済 システムの基本的構造の変革が要求される. 一方, 最も 楽観的なケースでも何らかの対策が必要である。なお， 対策のレベルは安定化させる温度に依存し，この温度を ビの程度にするかは影響シナリオに大きく依存するた め, この分野の研究も重要である.
5）不確実さを減らすことはできるか？

自然の不確定要因のうち大きなものは, 気候感度, 海 洋の影響, フィードバックなどであり, 今後の研究推進 によってある程度不確実さを減らせる可能性がある. し かし, これらの研究には長期間を要し, また, 解明され たとしても本質的に不確定要因の残る現象もある. 社会 経済的要因については, 人口政策や経済政策によって不 確実さを減らせる部分もあるが，その効果が出るには長 期間を要する. 不確実性について見通しがつくには時間 が必要である。

6) 温暖化防止対策の効果はどのくらい期待できる 加?

これから百年以上にわたって二酸化炭素排出量を毎年 $1 \%$ ずつ削減するという, 大変厳しい政策シナリオを 前提としなければ，気候安定化のシナリオを書くことが 難しい．この場合にかかる費用は，世界の総生産額の $10 \%$ 程度にもなる可能性がある. 二酸化炭素の排出量 を安定化させるだけでは，温暖化の時期を多少遅らせる 程度の効果しかない．気候安定化には大変な努力と時間 を必要とする.

7）防止対策のタイミングが遅れた場合，だれが困る か?

二酸化炭素排出量を毎年 $1 \%$ 削減する場合でも，現 世代の費用負担に比べて来世紀末の世代の負担は十倍以 上になる．もし，防止対策実施のタイミングが遅れたな らば，後世の世代の費用負担が増えるか，もしくは温暖 化による被害を後世の世代が受けることになる．政策対 応の遅れによって困るのは，現世代ではなく後世の世代 である。

8）現時点でどのような政策展開の方向が適切か？

以上の結果を総合すると, 可能な限り早いタイミング で出来るところから防止対策を導入し，後世の世代がと りうるオプションの幅を大きくするとともに，不確実の 程度と範囲を見極めるための時間を稼ぎ，併せて最悪の 温暖化シナリオに備えて社会経済システムの適応策を検 討しておくことが，ロバストな政策展開の方向と結論で きる。

最後に，本研究に関して残された課題を整理する.ま ず，本分析に用いた諸前提やパラメー夕は，最新の科学 的知見や将来の発展に関する認識に基づいて設定した が, 太陽活動, 大気エアロゾル等の不確定要因や，バッ クストップ技術などの革新的な技術導入について検討を 省略している．これは，もっぱら，本論文での分析範囲 を限定し，論理を明確にするためであり，別途，検討中 である.また，社会経済的な前提シナリオの設定におい て，人口増加と経済成長のようにシナリオ相互の関係に 配慮する必要があるが，今回はそれぞれ独立に与えた。 シナリオ相互の整合性についてさらに検討が必要であ 
る.なお，シミュレーション・モデルの予測結果につい ては, 現在, 同様なモデルとの比較分析を行っており, 本予測結果の妥当性を種々の局面から検証中である.

一方, 本研究に用いたモデルについては, 現在, 二つ の方向で改良を進めている. 一つは, アジア太平洋地域 において温室効果ガスの将来予測と対応策を検討するた め，これらの地域の国別モデルを開発して現在のモデル とリンク作業を行っている．他の一つは，温暖化の影響 シナリオを含めて総合的な政策判断ができるように，温 暖化影響モデルを開発して，現在のモデルと統合させる 予定である。

なお，本研究の遂行にあたっては，環境庁地球環境研 究総合推進費の援助を受けた。ここに記して感謝の意を 表す.

\section{文献}

1) Bacastow. R. and C. Keeling (1973) : Atmospheric carbon dioxide and radiocarbon in the natural carbon cycle changes from A.D. 1700 to 2070 as deduced from geochemical model. (in) G. Woodwell (ed.), Carbon and the biosphere, CONF-720510, Atomic Energy Commission, Washington D.C.

2) Barns, D.W., J.A. Edmonds and J.M. Reilly (1991) : Use of Edmonds-Reilly Model to Model Energy Related Greenhouse Gas Emissions for Inclusion in a OECD Survey Volume. mimeo, 9pp.

3) Bell, P. (1982) : Methane hydrate and the carbon dioxide question, (in) W. Clark (ed.) Carbon dioxide review 1982. Oxford, New York, 401-405.

4) Bilsborrow, R. E. (1989) : The demographics of macroeconomic demographic models. Population Buletin, 50. 39-83.

5) Bjoerkstorm, A. (1979) : A model of $\mathrm{CO}_{2}$ interaction between atmosphere, oceans and land biota, (in) The Global Carbon Cycle, Scope 13. B. Bolin et al, (eds.), John Wiley, 403-457.

6) Broecker, W.S. (1987) : Unpleasant surprises in the greenhouse?, Nature, 328, 123-126.

7) Bulatao, R.A., E. Bos, P.W. Stephens and M.T. Vu. (1990) : World population projections, 1989-90 editions. Short-and longterm estimates. The World Bank, John Hopkins Univ., 490pp.

8) Burniaux, J., J.P. Martin, G. Nicoletti and J.O. Martin (1991) : The Costs of Policies to Reduce Global Emissions of $\mathrm{CO}_{2}$ : Alternative Scenarios with GREEN, mimeo., 36pp.

9) Charlson. R., J. Lovelock, M. Andreae and S. Warren (1987) : Ocean phytoplankton, atmospheric sulphur, cloud albedo and climate, Nature, 326, 655-661.

10) Chamberlain, J.W., H.M. Foley, G.J. MacDonald and M.A. Ruderman (1982) : Climate effects of minor atmospheric constituents, (in) W.C. Clark, (ed.) Carbon dioxide review 1982, Oxford, New York, 255-277.

11) Edomonds, J. and J. Reilly (1983) : A long term global energy-economic model of carbon dioxide release from fossil fuel use. Energy Economics, 74-88.

12) Emanuel, W.R., H.H. Shugart and M.P. Stevensohn (1985) : Climate change and broad-scale distribution of terrestrial ecosystem complexes. Climatic Change, 7, 2943.

13) Gates, D. (1985) : Global biospheric response to increasing atmospheric carbon dioxido concentration, (in) Direct effects of increasing carbon dioxide on vegitation. Report DOE/ER-0238, U.S. Department of Energy, Washington, D.C..

14) 18) International Energy Agency (IEA) (1991) : Carbon Taxes and $\mathrm{CO}_{2}$ Emissions Targets : Results from the IEA Model. mimeo.

15) Hoeller, P. et al. (1990): A Survey of Studies of the Costs of Reducing Greenhouse Gas Emissions. OECD Working Paper, No. 89, 45p.

16) Houghton, R. (1990) : Projections of future deforestation and reforestation in the tropics, IPCC Tropical Forestry Response Options workshop, Sao Paulo, January 9-11, 1990.

17) Intergovernmental Panel on Climate Change, Working Group 1 (1992) : 1992 IPCC Supplement ; Full Scientific Report.

18) International Energy Agency (IEA) (1991) : Carbon Taxes and $\mathrm{CO}_{2}$ Emissions Targets : Results from the IEA Model. mimeo.

19) Joseph, D. (1991) : Climate model output data general information, 2 July 1991, NCAR, Boulder, USA.

20）霞が関地球温暖化問題研究会編訳 (1991)：IPCC 地球温 暖化レポート. 中央法規, 278p.

21）近藤次郎 (1983) : システム分析, 丸善, 271p.

22) Kvenvolden, K. (1988) : Methane hydrates and global climate, Global Biogeochemical Cycles, 2, 221-229.

23) Lovins, A.B., L.H. Lovins, F. Krause and W. Bach (1981) : Least-cost energy, solving the $\mathrm{CO}_{2}$ problem, Brick House Pub., Andover, USA.

24) Lashof, D. (1987): The role of the biosphere in the global carbon cycle : Evaluation through biosperic modeling and atmospheric measurement. Ph. D. Dissertation, Energy and Resources Group. University of California, Berkeley.

25) Lashof, D.A. (1989) : The dynamic greenhouse : feedback processes that may influence future concentrations of atmospheric trace gases and climate change, Climatic Change, 14, 213-242.

26) Lashof, D.A. et al. (1990) : Policy Options for Stabilizing Global Climate/Report to Congress. U.S. EPA. December 1990.

27) Lehman, S.J. and L.D. Keigwin (1992) : Sudden changes in North Atlantic circulation during the last deglaciation, Nature, 956, 757-762.

28) MacDonald, G.J. (1983) : The many origins of natural gas, J. Petrol, Geol., 5, 341-362.

29) MacDonald, G.J. (1990) : Role of Methane clathrates in past and future climates, Climatic Change, 18 247-281.

30) Mann, A.S. (1991) : Global 2100 : Alternative Scenario for Reducing Carbon Emissions, mimen., 20pp. 
31) Martin, J.H., Glacial-interglacial $\mathrm{CO}_{2}$ change : The iron hypothersis, Paleoceanography, 5 (1), 1-13.

32) Matthews, E. (1989) : Global data bases on distribution, characteristics and methane emission of natural wetlands : Documentation of archived data tape, NASA Technical Memorandum, 4153, 18pp.

33）松岡 譲 (1990)：温暖化現象の総合化モデルとそれによ る温室効果ガス濃度と上昇温度の将来推定について, 環 境システム研究, 18, 82-87.

34) Matsuoka, Y. (1992) : Projection of global climate change under carbon taxation using comprehensive global environmental model, Global Warming and Economic Growth (ed.) A. Amano, Center for Global Environmental Research, CGER-1001-'92, 99-110.

35）松岡 譫・森田恒幸 (1992)：地球温暖化におけるモデル と予測, 計測と制御, $31,577-585$.

36) McKinsey \& Company (1989): Protecting the Global Environment : Funding Mechanisms / Findings and Conclusions. Ministerial Conference on Atmospheric Pollution \& Climatic Change, 27p.

37) Melillo, J.M., J.R. Fruci, R.A. Houghton, B. Moore, III and D.L. Skole (1988) : Land-use change in the Soviet Union between 1850 and 1980 : cause of a net release of $\mathrm{CO}_{2}$ to the atmosphere, Tellus 40B, 116-128.

38) Mintzer, I. (1988) : Projecting future energy demand in industrialized countries : An end-use oriented approach. World Resources Institute, Washington, D.C.

39）森田恒幸 (1990a)：地球気候安定化のための政策オプ ションの体系. 季刊環境研究, No. 77, 21-29.

40）森田恒幸 (1990 b) : 地球気候安定化之経済的手段. 季刊 環境研究, No.77, 92-102.

41）森田恒幸 $(1990 \mathrm{c})$ ：地球温暖化にみる環境リスクの政策 分析. システム/制御／情報, 34 (10)，4-8.

42) Morita, T. (1992) : Aspects of Taxation for Protecting Global Environment. Global Warming and Economic Growth (ed.) A. Amano, Center for Global Environmental Rescarch, CGER-1001-'92, 12-16.

43）西岡秀三監訳 (1992) : 地球温暖化の影響予測/IPCC 第 2 作業部会報告書. 中央法規, 233 p.

44）西岡秀三・森田恒幸 (1992)：地球気候安定化のための社 会経済システムの構造転換政策の体系, 季刊環境研究, No. 86 .

45) Nordhaus, W.D. and G.W. Yohe (1983) : Future paths of energy and carbon dioxide emissions, (in) Changing Climate : Report of the carbon dioxide assessment committee, National Academy Press, Washington, DC. 87-153,

46) OECD Secretariat (1991) : Overview paper on costs of reducing $\mathrm{CO}_{2}$ emissions ; evidence for six global models, mimeo., 29pp.

47) Parry, M.L., M. Rozari, A.L. Chong et al. (eds.) (1992) :
The potential socio-economic effects of climate changes in South East Asia, United Nations Environment Programme, Nairobi, 126pp.

48) Patterson, D.T. and E.P. Flint (1990) : Implications of increasing carbon dioxide and climate change for plant communities and competition in natural and managed ecosystems, (in) Impact of carbon dioxide, trace gases, and climate change on global agriculture, ASA Special Publication No.53, 83-110.

49）クウエイド (Quade, E.S.) 他編 (1972)：システム分析 2 , 竹内畫店, $244 \mathrm{p}$.

50) RSWG (Response Strategies Working Group) of the Intergovernmental Panel on Climate Change (1990) : Emissions Scenaries, 58pp.

51) Revelle, R. (1983) : Methane hydrates in continental slope sediments and increcasing atmospheric carbon dioxide, (in) Changing Climate, National Academy Press, Washington D.C., 252-261.

52) Shugart, H. (1984) : A theory of forest dynamics, Springer, New York, 203-206.

53) Sarimiento, J.L. and E.T. Sundquist (1992) : Revised budget for the oceanic uptake of anthropogenic carbon dioxide, Nature, 356, 589-593.

54) Sathaye, J.A., A.N. Ketoff, L.J. Schipper and S.M. Lele (1987) : An end-use approach to development of long-term energy demand scenarios for developing countries, mimeo., 60pp.

55) Solomon, A. (1986) : Transient response of forests to $\mathrm{CO}_{2-}$ induced climate change : simulation modeling experiments in Eastern North America, Oecologia 68, 567-579.

56) Tans, P.P., I.Y. Fung and T. Takahashi (1990) : Observational constraints on the global atmospheric $\mathrm{CO}_{2}$ budget, Science, 247, 1431-1438.

57) The Task Force on the Comprehensive Approach to Climate Change (1991) : A comprehensive approach to addressing potential Climate Change, February 1991.

58) United Nations (1992) : Long-range world population projections, two centuries of population growth, 19502150. United Nations Publication, Sales No.E.92. XIII. 3.

59) U.S. Bureau of the Census (1987) : World population profile : 1987, U.S. Department of the Commerce, Washington, D.C.

60) U.S. National Academy of Sciences (1979) : Carbon dioxide and climate : a scientific assessment, Washington D.C., 22pp.

61) World Bank (1991) : World development report 1991, Oxford University Press, 290pp.

62) Woodwell, G. (1986) : Global warming : and what we can do about it, Amicus Journal 8, 8-12.

(1992. 6. 16受付) 